\title{
HUBUNGAN TINGKAT PENGETAHUAN DENGAN PERILAKU KONSUMSI TABLET Fe SAAT MENSTRUASI PADA MAHASISWI FKM UNAIR SURABAYA
}

\author{
Rohmanur Izzani \\ Departemen Biostatistika dan Kependudukan FKM UNAIR \\ Fakultas Kesehatan Masyarakat Universitas Airlangga \\ J1. Mulyorejo Kampus C Unair Surabaya 60115 \\ Alamat korespondensi: Rohmanur Izzani \\ Email: rohmanur.izzani-2016@fkm.unair.ac.id
}

\begin{abstract}
Anemia is one of the health problems in the world especially in developing countries and it is estimated that $30 \%$ of the world population suffers from anemia. Anemia is one of the health problems that often occur in pregnant women and young women. According to WHO (2013), the prevalence of anemia in the world reaches 40-88\%. According to Riskesdas (2013) got anemia patients in adolescent girls amounted to 2.7\%. One cause of high rates of anemia in adolescent girls is the lack of awareness of consumption of Fe tablets during menstruation. Consciousness of Fe tablet consumption during menstruation can not be separated from information and knowledge, because of knowledge is one of several factors that influence one's consumption behavior. The purpose of this study was to determine the relationship between knowledge with adolescent attitudes about consumption of Fe tablet during menstruation on students of Faculty of Public Health Unair Surabaya. This research was analytic with cross sectional approach. The samples were 50 respondents taken by simple random sampling technique. The instrument used a questionnaire. The result of this research was chi-square statistic test with significance level $\alpha=0,05$ or 95\%. Statistical test results obtained $p$ value $=1<\alpha=0.05$. The conclusion of this research is that there is no significant relationship of knowledge with attitude of Fe tablet consumption during menstruation on students of Faculty of Public Health Unair Surabaya.
\end{abstract}

Keywords: anemia, knowledge, attitude

\section{ABSTRAK}

Anemia merupakan salah satu masalah kesehatan di dunia terutama di negara berkembang dan diperkirakan 30\% penduduk dunia menderita anemia. Anemia merupakan salah satu masalah kesehatan yang sering terjadi pada ibu hamil dan remaja putri. Menurut WHO (2013), prevalensi anemia di dunia mencapai 40-88\%. Menurut Riskesdas (2013), prevalensi anemia gizi besi pada remaja sebesar $22,7 \%$. Salah satu penyebab tingginya angka anemia pada remaja putri adalah kurangnya kesadaran konsumsi tablet Fe pada saat menstruasi. Kesadaran konsumsi tablet Fe saat menstruasi tidak lepas dari informasi dan pengetahuan, hal ini disebabkan pengetahuan adalah satu dari beberapa faktor yang memengaruhi perilaku konsumsi seseorang. Tujuan penelitian ini adalah untuk mengetahui hubungan pengetahuan dengan sikap remaja tentang konsumsi tablet Fe saat menstruasi pada mahasisiwi FKM Unair. Penelitian ini bersifat analitik dengan pendekatan cross sectional. Sampel diambil dengan teknik simple random sampling yaitu sebanyak 50 responden. Instrumen yang digunakan dalam penelitian ini adalah kuesioner. Hasil penelitian menggunakan analisis uji statistik chi-square dengan tingkat kemaknaan $\alpha=0,05$ atau $95 \%$. Hasil uji statistik didapatkan nilai $p=1<\alpha=0,05$. Kesimpulan dari penelitian ini yaitu tidak ada hubungan bermakna pengetahuan dengan perilaku konsumsi tablet Fe saat menstruasi pada mahasiswi FKM Unair Surabaya.

Kata kunci: anemia, pengetahuan, sikap

\section{PENDAHULUAN}

Menurut Depkes RI (2011) remaja adalah yang berusia 10-19 tahun. Menurut WHO (2013) remaja adalah yang berusia 10-19 tahun. Berdasarkan data CSIS (2014) secara global, jumlah remaja (sebesar 25\% atau 1,8 miliar dari total penduduk dunia. Berdasarkan proyeksi penduduk pada tahun 2015, menunjukkan bahwa jumlah remaja Indonesia mencapai $>66$ juta atau 25\% dari 255 juta penduduk Indonesia (Bappenas, 2013). 
Definisi remaja adalah seseorang yang berusia 15-24 tahun (BKKBN, 2011). Menurut Soeparmanto dalam BKKBN (2010), pengetahuan dan perilaku reproduksi remaja saat ini akan memengaruhi dan berdampak pada generasi penerus bangsa.

Salah satu masalah remaja di Indonesia saat ini adalah anemia. Anemia pada remaja merupakan masalah kesehatan masyarakat, karena prevalensinya di atas $20 \%$. Anemia akibat kekurangan zat besi $(\mathrm{Fe})$ merupakan salah satu masalah gizi utama di Indonesia. Menurut data Riskesdas (2013), prevalensi anemia gizi besi pada remaja sebesar $22,7 \%$. Laporan berbagai studi di Indonesia memperlihatkan masih tingginya angka prevalensi anemia gizi pada remaja putri yang berkisar antara $20-50 \%$.

Anemia akibat kekurangan zat gizi besi $(\mathrm{Fe})$ merupakan salah satu masalah gizi utama di Asia termasuk di Indonesia. Pada anak usia sekolah, prevalensi anemia tertinggi ditemukan di Asia Tenggara dengan perkiraan sekitar $60 \%$ anak mengalami anemia.

Berdasarkan data Riset Kesehatan Dasar (Riskesdas) 2013, terdapat 21,7\% penduduk dengan kadar hemoglobin kurang dari batas normal yakni sebesar 18,4\% laki-laki dan sebesar $23,9 \%$ perempuan. Berdasarkan kelompok usia, $18,4 \%$ pada rentang usia $15-24$ tahun dengan kadar $\mathrm{Hb}$ kurang dari $12 \mathrm{~g} / \mathrm{dL}$.

Rata-rata banyaknya darah yang hilang pada wanita normal selama satu periode menstruasi telah ditentukan oleh beberapa kelompok peneliti, yaitu $25-60 \mathrm{ml}$. Konsentrasi $\mathrm{Hb}$ normal 14 gr per dl dan kandungan besi $\mathrm{Hb} 3,4 \mathrm{mg}$ per gr, volume darah ini mengandung 12-29 mg besi sehingga dapat memberikan gambaran kehilangan darah sebesar 0,4 sampai $1 \mathrm{mg}$ besi selama setiap hari siklus menstruasi atau sebesar 150 sampai 400 mg per tahun (Nur, 2010).

Setiap hari manusia kehilangan zat besi 0,6 mg yang diekskresi, khususnya melalui feses (tinja), remaja putri mengalami haid setiap bulan dengan kehilangan zat besi $\pm 1,3 \mathrm{mg}$ per hari, sehingga kebutuhan zat besi lebih banyak daripada pria. Bila asupan zat besi sebagai salah satu mikro nutrisi ini kurang terpenuhi, maka tubuh akan mengalami penurunan kadar hemoglobin, yang disebut dengan anemia. Akibat berkurangnya jumlah sel darah merah atau jumlah hemoglobin dalam sel darah merah tersebut, darah tidak dapat mentransfer oksigen dalam jaringan sesuai dengan jumlah yang diperlukan oleh tubuh. Oleh karena itu suplementasi zat besi pada remaja putri saat menstruasi menjadi suatu hal yang sangat penting.

Perilaku konsumsi tablet Fe saat menstruasi tidak terlepas dari informasi dan pengetahuan dari seorang remaja, hal ini dikarenakan pengetahuan merupakan faktor yang sangat memengaruhi perilaku konsumsi seseorang.

Mahasiswa merupakan kelompok usia peralihan dari masa remaja akhir menjadi dewasa awal yang lebih mandiri dalam menentukan makanan apa saja yang akan dikonsumsi. Masa remaja akhir dapat dilihat dengan pertumbuhan fisik yang melambat. Pada tahap ini, remaja akan lebih memfokuskan pada rencana yang akan datang dan meningkatkan pergaulan di lingkungan serta hidup lebih mandiri (Poltekkes Depkes Jakarta I, 2010).

Mahasiswa sebagai generasi penerus bangsa dan bagian dari masyarakat Indonesia diharapkan memiliki perilaku hidup yang sehat. Oleh karena itu, perlu adanya faktor-faktor pendukung yang mampu mengarahkan seorang mahasiswa untuk berperilaku menjaga kesehatannya, seperti misalnya mengonsumsi tablet $\mathrm{Fe}$ pada saat menstruasi. Faktor itu bisa berasal dari diri sendiri, keluarga, teman, maupun lingkungannya.

Faktor yang memengaruhi masalah gizi pada remaja diantaranya kurangnya pengetahuan dan kesadaran dalam mencukupi kebutuhan zat gizi tiap individu. Pengetahuan memengaruhi sikap dan perilaku dalam pemilihan makanan. Penggunaan suplementasi tablet $\mathrm{Fe}$ saat menstruasi dan selanjutnya akan berpengaruh terhadap keadaan gizi individu yang bersangkutan termasuk status anemia. (Khumaisi, 2009., Dept. Gizi KM UI, 2011)

Kesadaran konsumsi tablet $\mathrm{Fe}$ saat menstruasi tidak lepas dari informasi dan pengetahuan, hal ini disebabkan pengetahuan adalah salah satu faktor yang memengaruhi perilaku konsumsi seseorang. Kesadaran remaja 
dalam upaya pencegahan anemia melalui konsumsi tablet $\mathrm{Fe}$ masih rendah terbukti dengan analisis data Riskesdas (2007) prevalensi anemia pada remaja Indonesia mencapai 92,6\% (Hasrul, Hadju \& Citrakusumasari, 2010). Departemen Kesehatan (2011) menunjukkan penderita anemia pada remaja putri sebesar $26,50 \%$ dan WUS sebesar $26,9 \%$.

Hasil penelitian Weliyati \& Riyanto (2012) sebagian besar $(96,4 \%)$ remaja putri yang menjadi responden penelitian tidak berkeinginan mengonsumsi suplemen zat besi selama menstruasi ditambah minimal $1 \mathrm{x}$ seminggu, disebabkan kurangnya pengetahuan tentang pencegahan anemia pada saat remaja putri mengalami menstruasi.

Pengetahuan adalah hasil pengindraan manusia, atau hasil tahu seseorang terhadap objek melalui indera yang dimilikinya. Pengetahuan seseorang terhadap objek memiliki intensitas atau tingkat yang berbeda-beda. Selain itu, terdapat beberapa faktor yang memengaruhi pengetahuan seseorang yakni pendidikan, media massa, sosial budaya, lingkungan, dan pengalaman (Notoatmodjo, 2010).

Menurut penelitian Sihotang (2012), dapat ditarik kesimpulan bahwa pengetahuan remaja putri tentang anemia defisiensi besi mayoritas diperoleh informasi $50 \%$ diperoleh dari media (elektronik, cetak, internet), 25,5\% dari guru, $16 \%$ dari keluarga, dan $7,4 \%$ dari petugas kesehatan.

Pada sebuah penelitian Hapzah (2012) menerangkan bahwa responden dengan tingkat pengetahuan cukup cenderung menderita anemia dibandingkan dengan responden yang memiliki tingkat pengetahuan kurang.

Berdasarkan penjelasan di atas, maka rumusan masalah dalam penelitian ini adalah untuk mengetahui apakah terdapat hubungan antara tingkat pengetahuan dengan perilaku konsumsi tablet $\mathrm{Fe}$ pada saat menstruasi pada mahasiswi FKM UNAIR Surabaya yang dilaksanakan pada 22 Mei 2017.

\section{METODE PENELITIAN}

Penelitian ini menggunakan metode penelitian analitik yang bertujuan untuk menganalisis, menjelaskan suatu hubungan, menguji berdasarkan teori yang ada dengan menggunakan pendekatan cross sectional yaitu jenis penelitian yang menekankan waktu pengukuran atau observasi data variabel dependen dan independen dinilai hanya satu kali atau saat itu juga.

Populasi yaitu keseluruhan objek yang sedang diteliti atau diselidiki. Objek tersebut berupa manusia, hewan, tumbuh-tumbuhan, benda-benda mati lainnya, serta peristiwa dan gejala yang terjadi dalam masyarakat atau di dalam alam (Notoatmodjo, 2010). Populasi pada penelitian ini adalah mahasiswi FKM Unair Surabaya.

Pada penelitian ini teknik pengambilan sampel menggunakan simple random sampling. Teknik pengambilan sampel secara acak sederhana dengan cara undian diperoleh sejumlah 50 responden.

Teknik pengumpulan data dengan menggunakan kuesioner. Kuesioner yang akan digunakan dalam penelitian terlebih dahulu dilakukan uji validitas dan uji reliabilitas dengan karakteristik yang sejenis di luar lokasi penelitian.

Pengumpulan data yang dilakukan pada penelitian ini melalui tahapan: calon responden yang bersedia menjadi responden diberi lembar persetujuan (informed consent) dan lembar kuesioner dengan pertanyaan tertutup yang sudah disediakan jawabannya sehingga responden tinggal memilih. Peneliti memberikan penjelasan mengenai cara pengisian kuesioner dan memberikan kesempatan bagi responden untuk bertanya bila ada informasi yang kurang jelas. Responden diberi waktu untuk mengisi kuesioner dan peneliti melakukan pengawasan selama pengisian kuesioner. Kuesioner yang telah diisi dikembalikan kepada peneliti dan dilakukan pengecekan kembali untuk dilakukan pengolahan data.

Prosedur pengolahan data yang diawali dengan tahapan entry data atau memasukkan data ke computer untuk diolah dengan aplikasi.

Tahap selanjutnya yakni editing, yaitu pemeriksaan data yang telah terkumpul dari responden meliputi kesesuaian jawaban dan kelengkapan pengisian.

Tahap ketiga adalah coding yaitu pemberian kode terhadap jawaban responden. Coding 
Tabel 1. Distribusi Frekuensi Usia Responden

\begin{tabular}{ccc}
\hline Umur & Frekuensi & Persentase \\
\hline 17 & 3 & 6 \\
18 & 8 & 16 \\
19 & 16 & 32 \\
20 & 4 & 8 \\
21 & 5 & 10 \\
22 & 2 & 4 \\
23 & 6 & 12 \\
24 & 3 & 6 \\
25 & 2 & 4 \\
26 & 1 & 2 \\
\hline Total & 50 & 100 \\
\hline
\end{tabular}

dilakukan dengan pemberian kode 3 untuk pengetahuan baik, pengetahuan cukup diberi kode 2 dan pengetahuan kurang diberi kode 1 . Pada variabel terikat kode 1 jika mengonsumsi tablet Fe saat menstruasi dan kode 0 jika tidak mengonsumsi tablet $\mathrm{Fe}$ saat menstruasi.

Selanjutnya yakni scoring atau pemberian skor terhadap jawaban responden dengan cara jawaban benar diberi skor 1 dan skor 0 untuk jawaban salah.

Tahapan terakhir pengolahan data yakni tabulating yaitu tahapan di mana dari data mentah dilakukan penataan data, disusun dan disajikan dalam bentuk tabel distribusi frekuensi dan persentase.

Data dianalisis melalui prosedur analisis univariate dan bivariate dengan menggunakan uji chi-square pada tingkat kemaknaan $95 \%(\alpha$ $\leq 0,05$ ).

Analisis univariat dilakukan terhadap tiap variabel yang menghasilkan frekuensi dan presentase dari setiap variabel yang diteliti.

Sedangkan analisis bivariat adalah pengujian hipotesis yang bertujuan untuk mengetahui ada tidaknya hubungan antara dua variabel yaitu variabel bebas dengan skala data ordinal dan skala data nominal untuk variabel terikat maka menggunakan uji statistik Chi Square $\left(X^{2}\right)$.

Etika dalam penelitian ini adalah sebagai berikut: peneliti melakukan beberapa hal yang berhubungan dengan etika penelitian berupa
Tabel 2. Distribusi Kategori Pengetahuan tentang Tablet Fe

\begin{tabular}{lll}
\hline \multicolumn{1}{c}{ Kategori } & n & $\%$ \\
\hline Baik & 37 & 74 \\
Kurang & 13 & 26 \\
\hline Jumlah & 50 & \\
\hline
\end{tabular}

permintaan persetujuan responden pada lembar persetujuan penelitian (informed consent), tanpa nama (anonimity) dan kerahasiaan (confidentiality).

\section{HASIL PENELITIAN}

\section{Analisis Univariat}

Berdasarkan hasil penelitian pada tabel 1 menunjukkan bahwa distribusi frekuensi usia responden yaitu usia 17 tahun sebanyak $6 \%$ (3 orang), usia 18 tahun sebanyak 16\% (8 orang), usia 19 tahun sebanyak $32 \%$ (16 orang), usia 20 tahun sebanyak $8 \%$ (4 orang), usia 21 tahun sebanyak $10 \%$ (5 orang), usia 22 tahun sebanyak $4 \%$ ( 2 orang), usia 23 tahun sebanyak $12 \%$ (6 orang), usia 24 tahun sebanyak $6 \%$ (3 orang), usia 25 tahun sebanyak $4 \%$ ( 2 orang), dan usia 26 tahun $2 \%$ (1 orang).

Karakteristik responden merupakan ciri yang melekat secara alamiah dalam diri responden. Usia merupakan salah satu faktor internal yang penting untuk diketahui, mengingat usia berhubungan dengan tingkat kematangan jiwa seseorang dalam mengambil sebuah keputusan.

Distribusi pengetahuan responden berdasarkan tabel 2 menunjukkan bahwa mayoritas responden memiliki pengetahuan baik tentang manfaat mengonsumsi tablet $\mathrm{Fe}$ saat menstruasi, yaitu sebesar $74 \%$ (sebanyak 37 responden), dan sisanya memiliki pengetahuan kurang yaitu sebesar 26\% (sebanyak 13 responden).

Sedangkan distribusi perilaku konsumsi tablet $\mathrm{Fe}$ saat menstruasi dikelompokkan menjadi 2 (dua), yaitu mengonsumsi dan tidak mengonsumsi. Secara rinci dapat dilihat melalui tabel 3. 
Tabel 3. Distribusi Frekuensi Konsumsi Tablet Fe saat Menstruasi

\begin{tabular}{lcc}
\hline \multicolumn{1}{c}{ Kategori } & n & \% \\
\hline Mengonsumsi & 9 & 18 \\
Tidak & 41 & 82 \\
Mengonsumsi & & 100 \\
\hline Total & 50 & \\
\hline
\end{tabular}

Berdasarkan hasil penelitian di atas, hanya $18 \%$ responden yang mengonsumsi tablet $\mathrm{Fe}$ saat menstruasi, sedangkan sebanyak $82 \%$ responden tidak mengonsumsi tablet Fe saat menstruasi.

\section{Analisis Bivariat}

Berdasarkan tabel 4 dapat disimpulkan bahwa pengetahuan yang baik tidak selalu diikuti dengan perilaku konsumsi tablet $\mathrm{Fe}$ saat menstruasi. Pernyataan tersebut dapat menunjukkan bahwa tingkat pengetahuan mahasiswa tidak berkaitan dengan perilaku konsumsi tablet $\mathrm{Fe}$ pada mahasiswa Unair Surabaya.

\section{PEMBAHASAN}

Hasil penelitian ini juga menunjukkan bahwa gambaran pengetahuan responden tentang konsumsi tablet $\mathrm{Fe}$ saat menstruasi dalam kategori baik sebanyak 37 orang dengan persentase $74 \%$ sedangkan dan dalam kategori kurang sebanyak 13 orang dengan persentase $26 \%$.

Berdasarkan tabel 3 dapat diketahui bahwa responden yang mengonsumsi tablet $\mathrm{Fe}$ saat menstruasi sebanyak 9 orang (18\%) dan yang tidak mengonsumsi tablet $\mathrm{Fe}$ saat menstruasi sebanyak 41 orang $(82 \%)$.

Berdasarkan tabel 4 diketahui bahwa dari sampel 50 mahasiswi Fakultas Kesehatan Masyarakat Universitas Airlangga yang memiliki pengetahuan tentang konsumsi tablet $\mathrm{Fe}$ saat menstruasi dalam kategori baik sebanyak $74 \%$ dari total responden. Didapatkan sebanyak 19\% responden berpengetahuan baik yang mengonsumsi tablet $\mathrm{Fe}$ saat menstruasi, sedangkan responden berpengetahuan baik yang tidak mengonsumsi tablet $\mathrm{Fe}$ yaitu sebesar $\mathbf{8 1 \%}$.
Sedangkan untuk kategori responden dengan pengetahuan kurang yang mengonsumsi tablet Fe sebanyak $18 \%$ dan $82 \%$ responden tidak mengonsumsi tablet $\mathrm{Fe}$.

Proses pengolahan data pada penelitian ini menggunakan uji chi-square dengan $\alpha=0,05$ dan terdapat sel yang memiliki nilai $<5$ (Expected $<$ 5). Dengan demikian pada penelitian ini tidak bisa berakhir hanya dengan uji chi-square, maka analisis pada penelitian ini dilanjutkan dengan uji Fisher Exact, kemudian didapatkan $p$ value $=1$.

Berdasarkan hasil analisis tersebut, didapatkan $p$ value $>\alpha$ atau $1>0,05$, maka dapat disimpulkan bahwa $\mathrm{H}_{0}$ diterima, artinya tidak terdapat hubungan yang bermakna antara tingkat pengetahuan dengan perilaku konsumsi tablet Fe saat menstruasi pada mahasiswi FKM Unair Surabaya.

Hasil penelitian ini bertentangan dengan penelitian Aminah, S. \& Irianto, S. (2008) yang menyatakan bahwa pengetahuan tentang anemia mempunyai keterkaitan dengan kejadian anemia. Semakin tinggi tingkat pengetahuan, akan semakin baik pula perilaku remaja dalam mengonsumsi makanan sehingga dapat terhindar dari anemia. Hal tersebut sejalan dengan penelitian yang dilakukan oleh Tenri Yamin (2012) didapatkan pengetahuan remaja yang kurang $(83,3 \%)$ lebih tinggi menderita anemia dibandingkan dengan remaja dengan pengetahuan baik yang menderita anemia $(46,5 \%)$.

Hasil penelitian yang dilakukan oleh Widya (2017), menunjukkan bahwa pengetahuan dan kunjungan ANC berhubungan dengan kejadian anemia di Puskesmas Melur Tahun 2015. Dengan $p$ value masing-masing yaitu 0,001 dan 0,001 . Dari hasil penelitian maka dapat disimpulkan

Tabel 4. Hubungan Tingkat Pengetahuan dengan Konsumsi Tablet $\mathrm{Fe}$ saat Menstruasi

\begin{tabular}{lccc}
\hline \multirow{2}{*}{$\begin{array}{c}\text { Kategori } \\
\text { Pengetahuan }\end{array}$} & \multicolumn{2}{c}{$\begin{array}{c}\text { Konsumsi } \\
\text { Tablet Fe }\end{array}$} & Total \\
\cline { 2 - 3 } & Ya & Tidak & \\
\hline Baik & 7 & 30 & 37 \\
Kurang & 2 & 11 & 13 \\
\hline Total & 9 & 41 & 50 \\
\hline
\end{tabular}


bahwa terdapat hubungan antara pengetahuan ibu hamil dan kunjungan ANC dengan kejadian anemia di Puskesmas Melur tahun 2015.

Menurut Afifah (2015), tingkat pengetahuan yang tidak berhubungan dengan perilaku konsumsi tablet $\mathrm{Fe}$ ini mungkin juga dipengaruhi oleh adanya faktor pengganggu yang dominan yang menjadi penyebab remaja mengalami anemia. Variabel pengganggu tersebut dapat berasal dari status gizi yang kurang, pola makan yang kurang baik, serta penyakit lain meliputi cacingan atau malaria yang tidak diketahui, aktivitas fisik yang berlebih tidak diimbangi dengan nutrisi yang cukup, serta ekonomi yang berpengaruh pada daya beli pangan.

Hasil penelitian ini juga sejalan dengan penelitian Hapzah (2012) yang menyimpulkan bahwa responden yang memiliki pengetahuan cukup cenderung menderita anemia dibanding dengan responden yang memiliki pengetahuan kurang, sehingga tidak ada hubungan bermakna antara tingkat pengetahuan dengan kejadian anemia pada remaja putri $(p=0,258)$. Penelitian ini sejalan karena terdapat persamaan perilaku konsumsi makan remaja dan kurang optimalnya program pemerintah dalam melakukan pembinaan dan penyuluhan kesehatan kepada para remaja.

Pengetahuan yang dimiliki remaja belum diterapkan dalam kehidupan sehari-hari. Contohnya, remaja sudah mengetahui tentang sarapan sebagai salah satu penyebab anemia namun tetap masih banyak yang tidak sarapan sebelum berangkat sekolah. Hal ini menggambarkan bahwa pengetahuan belum dapat mengubah perilaku (Desri S, 2015).

Sedangkan berdasarkan penelitian Fatma (2010), di Negara Bangladesh sekitar 43\% remaja putri di desa menderita anemia dan lebih dari $50 \%$ remaja putri di daerah tersebut mengalami stunted yang disebabkan oleh berbagai faktor antara lain diskriminasi gender, rendahnya tingkat pendidikan, kemiskinan, kepercayaan, dan distribusi makanan dalam keluarga tidak merata.

Salah satu kelompok usia yang paling rentan jika kurang konsumsi sayur dan buah adalah remaja. Masa remaja merupakan periode yang penting pada pertumbuhan dan kematangan manusia. Pada periode ini merupakan saat yang tepat untuk membangun tubuh dan menanamkan kebiasaan pola makan yang sehat. Jika sejak remaja pola makan seseorang sudah tidak sehat, maka hal tersebut akan berdampak pada kesehatan yang akan datang.

Pola makan yang salah dan pengaruh pergaulan karena ingin langsing dan diet yang ketat menyebabkan berat badan turun. Mengonsumsi makanan dengan gizi seimbang akan memberikan energi yang cukup, sebaliknya akan berakibat menurunnya kemampuan otak, dan menurunnya semangat remaja dalam belajar. Takut berat badan naik dan kebiasaan makan yang tidak teratur penyebab anemia remaja (Balc YS, 2012)

Notoatmojo (2010) juga menganalisis bahwa kesehatan seseorang dipengaruhi oleh dua faktor pokok, yaitu faktor perilaku dan non perilaku. Faktor perilaku sendiri dipengaruhi oleh tiga faktor, yaitu faktor predisposisi (predisposing factors) yang meliputi pengetahuan, sikap kepercayaan, keyakinan, nilai-nilai, tradisi, faktor pemungkin (enabling factors) yang meliputi sarana dan prasarana untuk terjadinya perilaku kesehatan, dan faktor penguat (reinforcing factors) yang meliputi anjuran dari orang tua, keluarga, sahabat, guru, atau orang yang dianggap penting.

Konsumsi merupakan salah satu bentuk nyata perilaku yang sangat erat hubungannya dengan pengetahuan, namun sebelum orang tersebut berperilaku, terdapat proses adopsi yang melandasi munculnya perilaku seseorang. Salah satu proses adopsi perilaku yaitu trial (percobaan), pada tahap ini seseorang akan mencoba perilaku baru berdasarkan pengetahuan, kesadaran, sikap, terhadap stimulus. Apabila pada tahap trial ini seseorang memiliki pengetahuan tanpa ada kesadaran dalam bertindak berarti proses adopsi yang dilakukan gagal (Prasetya, dkk., 2012)

Dalam Notoatmojo (2010) perilaku (konsumsi tablet $\mathrm{Fe}$ ) tidak hanya dipengaruhi oleh faktor intern yang meliputi pengetahuan, tetapi dipengaruhi juga oleh faktor ekstern antara lain lingkungan serta faktor intern lainnya yaitu kecerdasan, persepsi, emosi, motivasi yang berfungsi untuk mengolah rangsangan dari luar. 
Sehingga dapat dijelaskan jika pada kategori pengetahuan baik maupun cukup terdapat mahasiswa yang tidak mengonsumsi tablet $\mathrm{Fe}$ saat menstruasi bisa saja dikarenakan karena motivasi dan kesadaran yang rendah sehingga kemampuan mengolah rangsangan dari luar juga rendah.

Salah satu faktor yang memiliki pengaruh besar terhadap terjadinya perilaku seseorang yaitu faktor sosio-psikologis. Faktor-faktor sosio-psikologis ini terdiri dari sikap, emosi, kepercayaan, kebiasaan, dan kemauan (Notoatmodjo, 2010).

Hal ini juga sesuai dengan hasil penelitian Puspasari, Saryono \& Ramawati (2008) bahwa faktor-faktor yang memengaruhi konsumsi tablet $\mathrm{Fe}$ antara lain pengetahuan, tingkat pendidikan, sikap, sosial ekonomi, fasilitas sarana kesehatan, perilaku petugas kesehatan, peran serta keluarga, nilai positif, kepercayaan, keyakinan yang memengaruhi kemauan remaja dalam mengonsumsi tablet $\mathrm{Fe}$.

Hal ini didukung oleh hasil penelitian Gunatmaningsih (2007) dengan judul "FaktorFaktor yang Berhubungan dengan Kejadian Anemia pada Remaja Putri di SMA Negeri 1 Kecamatan Jatibarang Kabupaten Brebes". Hasil penelitian menunjukkan bahwa terdapat hubungan yang signifikan dengan kejadian anemia pada remaja putri di SMA Negeri 1 Kecamatan Jatibarang Kabupaten Brebes adalah keluarga $(\mathrm{p}=0,035)$, tingkat pendidikan ibu ( $\mathrm{p}$ $=0,040)$.

Selain itu, tingkat pendidikan adalah salah satu faktor yang memengaruhi kejadian anemia. Hal ini diperkuat oleh penelitian Nur intan Kusuma (2014) dengan judul "Pengaruh Pendidikan Kesehatan Anemia Pada Remaja Putri Terhadap Tingkat Pengetahuan Dan Sikap Dalam Mencegah Anemia Pada Siswi Kelas X SMA Muhammadiyah 5 Yogyakarta". Hasil penelitian menyatakan bahwa ada pengaruh pendidikan kesehatan tentang anemia pada remaja putri terhadap tingkat pengetahuan dan sikap dalam mencegah anemia pada siswi kelas X SMA Muhammadiyah 5 Yogyakarta.

Perlu adanya program pencegahan dan penanggulangan untuk menanggulangi masalah kesehatan pada remaja khususnya anemia. Diharapkan prevalensi anemia dapat menurun sehingga kesehatan generasi muda dapat terjamin. Keberhasilan program penanggula- ngan anemia pada remaja putri ini tercapai apabila terdapat kerjasama yang baik antar lintas sektor meliputi dinas kesehatan, dinas pendidikan, dukungan keluarga serta masyarakat.

Penelitian ini masih terdapat beberapa keterbatasan. Keterbatasan tersebut adalah peneliti tidak faktor atau variabel yang memengaruhi pengetahuan dan sikap. Pada waktu pengisian kuesioner responden terlihat ada yang kurang teliti dalam menjawab. Kuesioner yang digunakan merupakan kuesioner tertutup sehingga responden tidak bisa menuangkan pendapatnya secara luas karena terbatas pada pilihan jawaban ya atau tidak.

\section{SIMPULAN DAN SARAN}

\section{Simpulan}

Responden yang memiliki tingkat pengetahuan baik sebanyak $74 \%$ dan responden yang memiliki tingkat pengetahuan tidak baik sebesar $26 \%$. Responden yang mengonsumsi tablet $\mathrm{Fe}$ saat menstruasi sebesar $18 \%$ dan responden yang tidak mengonsumsi tablet $\mathrm{Fe}$ saat menstruasi sebanyak $82 \%$.

Pengetahuan mahasiswi FKM Unair terkait manfaat tablet Fe sebagian besar memiliki tingkat pengetahuan yang baik dalam memahami manfaat konsumsi tablet Fe. Meski demikian, sebagian besar mahasiswi FKM Unair Surabaya memiliki sikap negatif atau tidak mengonsumsi tablet $\mathrm{Fe}$ saat menstruasi meskipun pengetahuannya terkait hal tersebut sudah baik. Maka dapat disimpulkan bahwa tidak ada hubungan bermakna antara tingkat pengetahuan dengan perilaku konsumsi tablet Fe saat menstruasi pada mahasiswi FKM Unair Surabaya Tahun 2016.

\section{Saran}

Pada penelitian ini dapat disimpulkan bahwa meskipun pengetahuan mahasiswa dapat dikategorikan tinggi, namun sebagian besar mahasiswa tidak mengonsumsi tablet $\mathrm{Fe}$ saat menstruasi. Secara statistik dari penelitian didapatkan bahwa tingkat pengetahuan tidak berhubungan dengan perilaku mengonsumsi tablet Fe saat menstruasi, maka diharapkan 
adanya upaya penyadaran secara terus menerus melalui berbagai kesempatan dan pendekatan.

Bagi mahasiswa FKM Unair diharapkan berupaya untuk meningkatkan pengetahuan tentang anemia dan menerapkan dalam kehidupan sehari-hari dengan mengonsumsi makanan bergizi. Selain itu, berdasarkan hasil penelitian ini, pemerintah melalui Dinas Kesehatan diharapkan mencanangkan program suplementasi tablet Fe bagi remaja putri semasa SMA dan kuliah di perguruan tinggi sampai menikah dan masa kehamilan karena manfaatnya begitu besar, bukan hanya untuk ibu, namun untuk kesehatan generasi bangsa di masa mendatang.

\section{DAFTAR PUSTAKA}

Aminah, S., Irianto, S. 2008. Status Anemia, Perilaku dan Pengetahuan Gizi Serta Kesehatan Reproduksi. Tersedia di: http:// jurnal.unimus.ac.id/index.php/psn12012010/ article/view/126/107 [diakses tanggal 25 Juli 2018].

Balc YS, M.D., Aysun Karabulut, M.D., Dolu nay Gürses M.D., Ibrahim Ethem Çövüt, M.D. 2012. Prevalence and Risk Factors of Anemia among Adolescents in Denizli, Turkey. Journal of Pediatr, Vol 22. No 1, Maret 2012, pp: 77-81 [diakses tanggal 01 Agustus 2018].

Bappenas, BPS. 2013. Proyeksi Penduduk Indonesia 2015. Tersedia di: http://www. bappenas.go.id/ [diakses tanggal 2 April 2018].

BKKBN. 2010. Remaja Genre dan Perkawinan Dini. Tersedia di: http://www. bkkbn.go.id/remaja-genre-dan-pernikahandini/. [diakses tanggal 02 April 2018].

Departemen Gizi dan Kesehatan Masyarakat FKM Universitas Indonesia. 2011. Gizi dan Kesehatan Masyarakat. Jakarta: Raja Grafndo Persada.

Depkes RI. 2011. Profil Kesehatan Indonesia. Jakarta: Depkes RI.

Desri Suryani, Riska Hafiani, Rinsesti Junita. 2015. Analisis Pola Makan dan Anemia Gizi Besi pada Remaja Putri Kota Bengkulu. Jurnal Kesehatan Masyarakat. FKM Universitas Andalas. Tersedia di: http://jurnal.fkm.unand. ac.id/index.php/jkma/ [diakses tanggal 01 Agustus 2018].

Fatma. 2010. Pengalaman Negara Lain dalam Perbaiakan Gizi Remaja Sekolah Meenengah. Jurnal Kesehatan, Vol. 60, No. 2, Februari 2010 [diakses tanggal 01 Agustus 2018].

Gunatmaningsih, D. 2007. Faktor-Faktor yang Berhubungan dengan Kejadian Anemia pada Remaja Putri di SMA Negeri 1 Kecamatan Jatibarang Kabupaten Brebes Tahun 2007. Jurnal Unnes. Tersedia di: http://lib.unnes. ac.id/1102/1/2676.pdf [diakses tanggal 01 Agustus 2018].

Hapzah. 2012. Hubungan Tingkat Pengetahuan dan Status Gizi Terhadap Kejadian Anemia Remaja Putri pada Siswi Kelas III di SMA N 1 Tinambung Kabupaten Polewali Mandar Sulawesi Barat. [diakses tanggal 01 Agustus 2018].

Kemenkes RI. 2013. Riset Kesehatan Dasar; RISKESDAS. Jakarta: Balitbang Kemenkes RI.

Kusuma, N. I. 2014. Pengaruh Pendidikan Kesehatan Anemia pada Remaja Putri Terhadap Tingkat Pengetahuan dan Sikap dalam Mencegah Anemia pada Siswi Kelas X SMA Muhammadiyah 5 Yogyakarta Tahun 2014. Tersedia di: https://www.google.com/search?q=K suma $\% 2 \mathrm{C}+\mathrm{N} \% 2 \mathrm{C} . \mathrm{I} .+2014$. + Pengar uh+Pendidik. [diakses tanggal 01 Agustus 2018].

Notoatmodjo, S. 2010. Ilmu Perilaku Kesehatan. Jakarta: PT Rineka Cipta.

Nur, Dewi Kartikasari. 2010. Hubungan antara Pengetahuan dan Sikap tentang Anemia dengan Keteraturan Mengonsumsi Tablet Fe pada Ibu Hamil di BPS "X". Jurnal Universitas Negeri Solo. Tersedia di: http:// digilib.uns.ac.id/ [diakses tanggal 01 Agustus 2018].

Permaesih, D., Herman, S. 2005. Faktor-faktor yang Memengaruhi Anemia pada Remaja. Buletin Penelitian Kesehatan, Vol. 33 No. 4, Tahun 2005, pp: 162-171 [diakses tanggal 01 Agustus 2018].

Poltekkes Depkes Jakarta I. 2010. Kesehatan Remaja: Problem dan Solusinya. Jakarta: Salemba Medika. 
Prasetya Lestari, Widardo, Sri Mulyani. 2015. Pengetahuan Berhubungan dengan Konsumsi Tablet Fe saat Menstruasi pada Remaja Putri di SMAN 2 Banguntapan Bantul. Jurnal Ners dan Kebidanan Indonesia, Volume 3 Nomor 3, pp: 145149 [diakses tanggal 01 Agustus 2018].

Puspasari, Fida Dyah., Saryono., Rahmawati, Dian. 2008. Faktor-Faktor yang Memengaruhi Kepatuhan Ibu Hamil dalam Mengonsumsi Tablet Besi di Desa Sokaraja Tengah. Jurnal keperawatan Soedirman (The Soedirman Journal of Nursing) Volume 3 Nomor 1, Maret 2008. [diakses 01 Agustus 2018].

RISKESDAS. Riset Kesehatan Dasar. 2013. Jakarta: Badan Penelitian dan Pengembangan Kesehatan, Depkes RI.

Riyanto, Weliyati. 2012. Faktor Terjadinya Anemia pada Remaja Putri di SMA Negeri Kota Metro. Jurnal Kesehatan Metro Sai Wawai. Terdapat di: https://ejurnal.poltekkestjk.ac.id/index. php/ [diakses tanggal 25 Juli 2018].

Sihotang, S. 2013. Pengetahuan dan Sikap Remaja Putri Tentang Anemia Defisiensi Besi di SMA Negeri 15 Medan. Medan: FK USU [diakses 25 Juli 2018].

Widya Juliarti. 2017. Hubungan Faktor Penyebab dengan Kejadian Anemia di Puskesmas Melur. Jurnal Penelitian Kesehatan Forikes, Volume VIII Nomor 1, ISSN 2086-309 [diakses tanggal 01 Agustus 2018].

World Health Organization. Adolescent Health. Information System. Geneva: WHO 2013. Tersedia di: http://www.who.int/ adolescenthealth/. [diakses 01 Agustus 2018].

Yamin, T. 2012. Hubungan Pengetahuan, Asupan Gizi dan Faktor Lain yang Berhubungan dengan Kejadian Anemia Pada Remaja Putri di SMA Kabupaten Kepulauan Selayar. Jurnal FKM Universitas Indonesia Depok. [diakses 01 Agustus 2018]. 